\title{
A Case of Giant Hyperkeratotic Cutaneous Leishmaniasis in the Penis
}

\section{Peniste Dev Hiperkeratotik Kutanöz Layşmanyazis Olgusu}

\author{
Mehmet Gülüm¹, Yavuz Yeşilova ${ }^{2}$, Murat Savaş ${ }^{1}$, Halil Çiftçi ${ }^{1}$, Ercan Yeni ${ }^{1}$, Fadile Yıldız Zeyrek ${ }^{3}$ \\ ${ }^{1}$ Department of Urology, Faculty of Medicine, Harran University, Şanlıurfa, Turkey \\ 2Department of Dermatology, Faculty of Medicine, Harran University, Şanlıurfa, Turkey \\ ${ }^{3}$ Department of Microbiology, Faculty of Medicine, Harran University, Şanlıurfa, Turkey
}

\begin{abstract}
Cutaneous leishmaniasis is a protozoan disease caused by leishmanias, which results in deformations of the skin. Cutaneous leishmaniasis is endemic in the southeastern parts of Turkey. Cutaneous leishmaniasis is the most common form and is often observed in open regions of the body. Involvement of the penis was rarely reported. In this paper, we present a case of a giant hyperkeratotic form of cutaneous leishmaniasis in the glans penis. (Turkiye Parazitol Derg 2013; 37: 53-4)
\end{abstract}

Key Words: Cutaneous leishmaniasis, glans penis, giant, hyperkeratotic

Received: 20.06 .2012

Accepted: 05.12 .2012

\section{ÖZET}

Kutanöz layşmanyazis ciltte deformitelerle sonuçlanan, Leishmania türlerinin neden olduğu bir protozoal enfeksiyondur. Türkiye'nin güneydoğu bölgesinde endemik olarak görülmektedir. Kutanöz layşmanyazis en yaygın formdur ve sıklıkla vücudun açık bölgelerinde görülür. Penis tutulumu nadir bildirilmiştir. Bu yazıda, glans peniste kutanöz layşmanyazis'in dev hiperkeratotik formu ile seyreden bir olgu sunulmuştur. (Turkiye Parazitol Derg 2013; 37: 53-4)

Anahtar Sözcükler: Kutanöz layşmanyazis, glans penis, dev, hiperkeratotik

Geliş Tarihi: 20.06.2012 Kabul Tarihi: 05.12.2012

\section{INTRODUCTION}

Leishmaniasis is a parasitic disease and a public health problem, which is caused by protozoa of the genus Leishmania. It is one of the leading conditions observed in people with skin disorders who travel from tropical countries (1). Leishmaniasis is categorized as cutaneous, mucosal, and visceral. Patients with leishmaniasis make up $90 \%$ of Cutaneous leishmaniasis (CL) cases (2). Localization of CL in the penis is rare. In this case, there was a giant hyperkeratotic type of $\mathrm{CL}$ in the glans penis.

\section{CASE REPORT}

A 45-year-old male patient was admitted to our clinic with the complaint of a crusty scar on his penis, which had been present for approximately 4 years. The patient was not previously admitted to any health institution and had experienced difficulty in sexual intercourse over the previous 1 year. The patient had not previously received any treatment. Dermatological examination showed hyperkeratotic plates, which fully spread in the glans penis, with a slightly indurated base and sometimes seuro-hemorrhagic crust lesion

Address for Correspondence / Yazışma Adresi: Dr. Yavuz Yeşilova, Department of Dermatology, Faculty of Medicine, Harran University, Şanlıurfa, Turkey Phone: +90505 5029398 E-mail: yavuzyesilova@gmail.com doi:10.5152/tpd.2013.13 


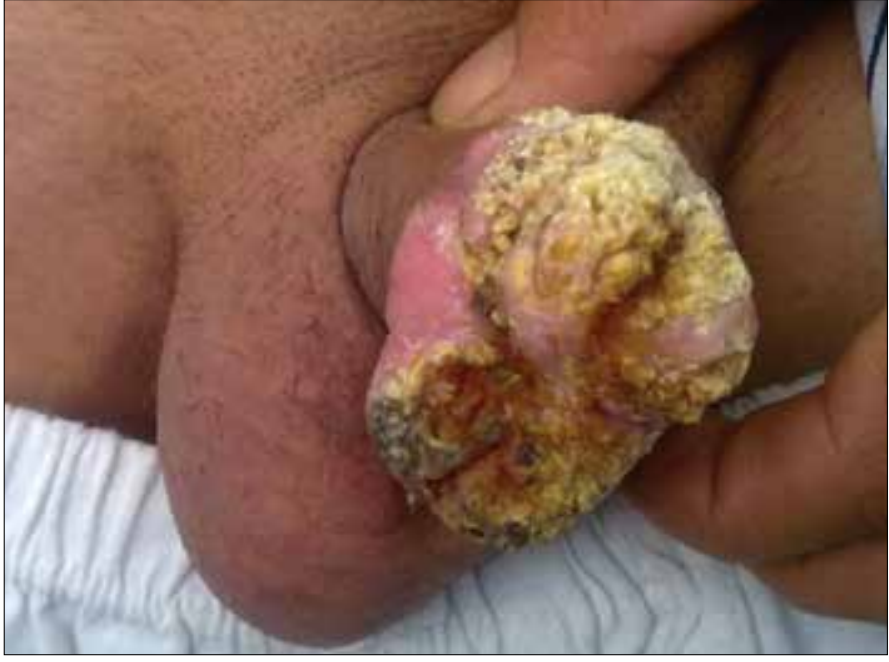

Figure 1. A non-healing hyperkeratotic plates, which fully spread in the glans penis

and fissure (Figure 1). Leishmaniasis smear was positive (Figure 2); other laboratory tests were normal. Benign and malignant skin tumors were excluded based on excisional skin biopsy collected from the hyperkeratotic lesion. The patient received intralesional meglumine antimoniate treatment (twice weekly, for 8 weeks) and the treatment continued with $20 \mathrm{mg} / \mathrm{kg}$ meglumine antimoniate. During the course of the treatment, an improvement was observed in the hyperkeratotic plates and shrinkage of the lesion. However, the patient was planned to receive a secondary $20 \mathrm{mg} / \mathrm{kg}$ meglumine antimoniate treatment, but did not attend subsequent controls.

\section{DISCUSSION}

It is estimated that leishmaniasis affects approximately 12 million people in 90 countries. The World Health Organization included leishmaniasis as a serious tropical disease for research, along with malaria, leprosy, dengue fever, hemorrhagic fever, filariasis and trypanosomiasis (1). Şanlıurfa Province, in southeastern Anatolia, Turkey, is highly endemic for CL and has drawn considerable attention (3). CL is generally observed in open regions of the body such as the face, eyelids, forehead, hands, wrists and sometimes the legs. The literature includes several cases of $\mathrm{CL}$ localized in the penis (4-7). The majority of penis lesions are destructive, painless and slowly progressing ulcers that resemble scabies ulcers (6). Unlike previously reported cases, there was a giant and hyperkeratotic CL I in our patient.

The lesion of our patient was hyperkeratotic and underwent a long development period. Since $C L$ is locally endemic, we suspected CL in this lesion, which had not healed for a long time. Smear tests were performed and found to be positive. Leishmaniasis culture negative. CL was considered after subsequent serologic evaluation. However, excisional biopsy was also conducted, to exclude skin malignity due to localization, clinical outlook and long history.

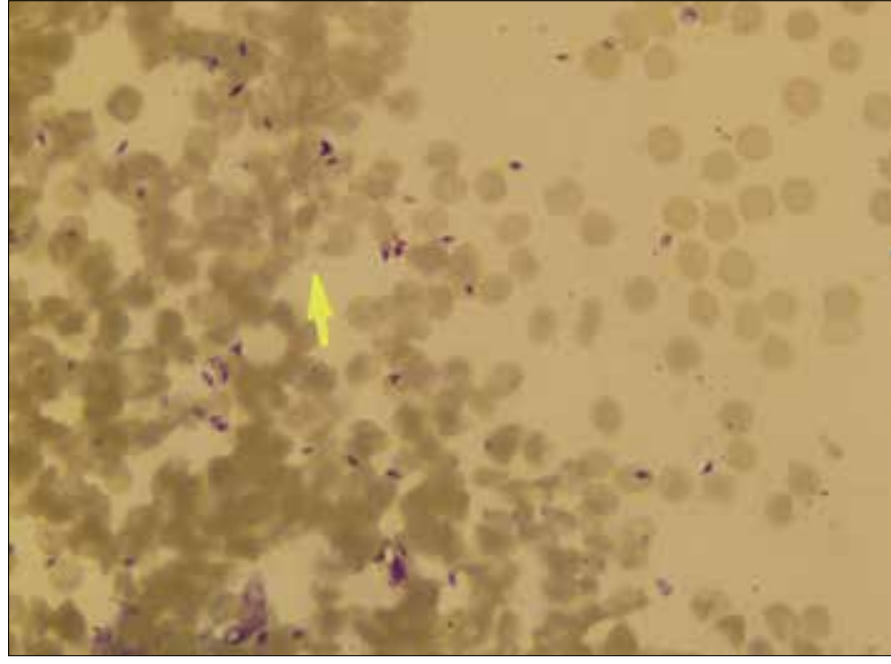

Figure 2. The typical presentation of amastigotes in a smear preparation, stained with Giemsa

\section{CONCLUSION}

Cutaneous leishmaniasis should be considered for lesions that do not heal for a long time in individuals who live or travel to regions that have a high risk of $C L$, no matter whether lesions are located in covered or non-covered areas. In addition, in nonrecessing, long-term cases in the genital area, an extensive distinctive diagnosis would be considered; in particular, benign and malignant skin tumors should be excluded via laboratory tests and skin biopsies.

\section{Conflict of Interest}

No conflict of interest was declared by the authors.

\section{REFERENCES}

1. Ono M, Takahashi K, Taira K, Uezato H, Takamura S, Izaki S. Cutaneous leishmaniasis in a Japanese returnee from West Africa successfully treated with liposomal amphotericin. $\mathrm{Br} \mathrm{J}$ Dermatol 2011; 38: 1062-5. [CrossRef]

2. Gontijo CM, da Silva ES, de Fuccio MB, de Sousa MC, Pacheco RS, Dias ES, et al. Epidemiological studies of an outbreak of cutaneous leishmaniasis in the Rio Jequitinhonha Valley, Minas Gerais, Brazil. Acta Trop 2002; 81: 143-50. [CrossRef]

3. Gurel MS, Ulukanligil M, Ozbilge H. Cutaneous leishmaniasis in Sanliurfa: epidemiologic and clinical features of the last four years (1997-2000). Int J Dermatol 2002; 41: 32-7. [CrossRef]

4. Masmoudi A, Boudaya S, Bouzid L, Frigui F, Meziou TJ, Akrout F, et al. Penile sporotrichoid cutaneous leishmaniasis. Bull Soc Pathol Exot 2005; 98: 380-1.

5. Schubach A, Cuzzi-Maya T, Gonçalves-Costa SC, Pirmez C, OliveiraNeto MP. Leishmaniasis of glans penis. JEADV 1998; 10: 226-8. [CrossRef]

6. Castro Coto A, Hidalgo Hidalgo H, Solano Aguilar E, Coto Chacón F. Leishmaniasis of the genital organs. Med Cutan Ibero Lat Am 1987; 15: 145-50.

7. Grunwald MH, Amıchai B, Trau H. Cutaneous leishmaniasis on an unusual site: the glans penis. Br J Urol 1998; 82: 928. [CrossRef] 